\title{
Matrix-oriented Layout: System Construction of the Government Guide on the Network Public Opinion
}

\author{
Xiu-Min JIANG, Bo WEN
}

School of Public Administration and Humanities, Dalian Maritime University, Liaoning Dalian, China

Keywords: Net Citizen, Network Public Opinion, Network Public Opinion Guidance, Government Micro-blog.

\begin{abstract}
In recent years, the situation of network public opinion in China is becoming more complex, which causes a series of social problems. Therefore, it is urgent for the government to strengthen the guidance and governance of the network public opinion. The current government has adopted a series of measures enacted laws and regulations relevant regulations, take some effective ways and means to guide network public opinion, but with the new situation of the development of the network public opinion, the government is still facing difficult challenges and dilemmas, through in-depth analysis of guide the specific work of the government network public opinion, proposed building a matrix-oriented layout to guide effective countermeasures of network public opinion.
\end{abstract}

\section{Introduction}

In the era of "everyone is a microphone", the network has become a new platform for public opinion expression. Network opinions will evolve into the network public opinion, when it based on common interests appeals to proliferate and form consistent opinion tendency. In recent years, the noise of network public opinion on the surface in China seems to keep quiet, but in fact, the dark has surged. On the one hand, the Chinese government has taken better measures to control the Internet, the positive energy topic begins to win discourse power in the public opinion field, meanwhile, the situation of the network public opinion has slowed down. On the other hand, there are some prominent problems, including network security and ideological problems. Therefore, it has become a great urgent task to strengthen the guidance and governance of the network broadcast opinion under the new situation.

\section{Current Network Public Opinion Guidance Measures}

At present, in order to strengthen guidance to the network public opinion, Chinese government has promulgated relevant laws and regulations and formulated a series of effective policies. The government has gradually diversified the way of guiding the network public opinion, taking "two ends and one end” as its main body and gradually introducing other new media tools, network media guide effect is remarkable.

\section{Promulgated the Relevant Laws and Regulations and Policies to Guide the Network Public Opinion}

In order to regulate Internet information activities and promote the orderly development of the Internet, the "Measures for the Administration of Internet Information Services" were promulgated in September 2000, which stipulates that the release of Internet information is subject to the law. Since then, according to the various problems that the government emerged in the guidance of network public opinion, a number of laws and regulations were promulgated one after another, aiming to enhance the government's ability to respond and guide the network public opinion. As showed in Table 1: 
Table 1

\begin{tabular}{|c|c|c|}
\hline time & name & content \\
\hline $\begin{array}{l}2008-5-1 \\
\text { begin to be } \\
\text { implemented }\end{array}$ & $\begin{array}{l}\text { Regulations on information } \\
\text { disclosure of the } \\
\text { government of the } \\
\text { government of the People's } \\
\text { Republic of china }\end{array}$ & $\begin{array}{l}\text { Within the scope of the government's initiative to open the } \\
\text { information, and the administrative organ should voluntarily disclose } \\
\text { it through a way that the public can easily know }{ }^{[1]}\end{array}$ \\
\hline 2012-12 & $\begin{array}{l}\text { Decision of the standing } \\
\text { Committee of the National } \\
\text { people's Congress on } \\
\text { enhancing the protection of } \\
\text { network information }\end{array}$ & $\begin{array}{l}\text { The network service providers should strengthen the management of } \\
\text { information published by its users, find out that the laws and } \\
\text { regulations prohibit or transmit information, stop it immediately, } \\
\text { take measures such as elimination and disposal, preserve relevant } \\
\text { records, and report to the competent departments concerned. }\end{array}$ \\
\hline 2013-10 & $\begin{array}{l}\text { The general office of the } \\
\text { State Council further } \\
\text { strengthens public } \\
\text { information, in order to } \\
\text { respond to social concerns } \\
\text { about promotion of the } \\
\text { Government's credibility }\end{array}$ & $\begin{array}{l}\text { All localities and departments should make public opinion collection } \\
\text { and analysis work, and timely respond to doubts, misunderstandings, } \\
\text { even distortions and rumors of government work in the form of } \\
\text { online news release, expert interpretation, news conference and } \\
\text { media interviews. The relevant competent departments should } \\
\text { further increase monitoring of the network public opinion, and set up } \\
\text { monitoring reports for important public opinions, timely transfer } \\
\text { relevant local governments and departments concern and response. }{ }^{[3]}\end{array}$ \\
\hline 2013-11 & $\begin{array}{l}\text { The interpretation of } \\
\text { applicable law of the } \\
\text { Supreme People's court and } \\
\text { the Supreme People's } \\
\text { Procuratorate on the } \\
\text { application of defamation in } \\
\text { the use of information } \\
\text { network }\end{array}$ & $\begin{array}{l}\text { If the information network is used to smear others, if the same libel } \\
\text { information is actually clicked or visited for more than } 5000 \text { times, } \\
\text { or the number of times being forwarded to more than } 500 \text { times, it } \\
\text { should be identified as "serious circumstances" stipulated in the first } \\
\text { paragraph of the } 246 \text { th criminal law, which can constitute libel. }{ }^{[4]}\end{array}$ \\
\hline 2016-8 & $\begin{array}{l}\text { Notifications of further } \\
\text { response to government } \\
\text { public opinion in public } \\
\text { affairs }\end{array}$ & $\begin{array}{l}\text { Clear government public opinion response responsibility, grasp the } \\
\text { key to respond the government public opinion standards, and } \\
\text { improve government public opinion responsive effectiveness. For a } \\
\text { major event, a major emergency and government public opinion, we } \\
\text { should respond quickly and timely, and press conference should be } \\
\text { held within } 24 \text { hours at the latest. We should respond to other public } \\
\text { opinion within } 48 \text { hours. }{ }^{[5]}\end{array}$ \\
\hline 2016-11 & $\begin{array}{l}\text { Comments on the overall } \\
\text { promotion the public work } \\
\text { of government affairs } \\
\text { (implementation rules) }\end{array}$ & $\begin{array}{l}\text { Around the major policies and regulations of the State Council, } \\
\text { planning and executive meeting of the State Council agreed } \\
\text { matters,It should actively resolve doubts, guide domestic public } \\
\text { opinion, influence international public opinion, manage social } \\
\text { expectations by attending the press conference of the State Council, } \\
\text { writing articles. Reading media interviews and online interviews for } \\
\text { policy interpretation. Make full use of the central news media and its } \\
\text { website, through micro-blog, We-Chat and clients do a good job in } \\
\text { the interpretation of the State Council's major policies, play a } \\
\text { "directional tuning" role of mainstream media, and correctly guide } \\
\text { public opinion }{ }^{[6]}\end{array}$ \\
\hline $\begin{array}{l}\text { Enacted in } \\
2016-11-23 \\
2017-6-1 \\
\text { begin to } \\
\text { implement }\end{array}$ & $\begin{array}{l}\text { National security network } \\
\text { law }\end{array}$ & $\begin{array}{l}\text { The state should actively carry out cyberspace governance, network } \\
\text { technology research and development, standards formulation, crack } \\
\text { down on Internet crime and other aspects of international exchanges } \\
\text { and cooperation, promote the construction of a peaceful, safe, open } \\
\text { and cooperative network space, and establish a multilateral, } \\
\text { democratic and transparent network governance system. }{ }^{[8]}\end{array}$ \\
\hline 2017-5 & $\begin{array}{l}\text { Regulations on the } \\
\text { management of Internet } \\
\text { news information services }\end{array}$ & $\begin{array}{l}\text { Detailed provisions are made on the license, operation, supervision } \\
\text { and inspection and legal liability of the Internet news information } \\
\text { dissemination. It's clear that the Internet news information service } \\
\text { providers are required to apply for the license, and activities within } \\
\text { the law; local and national Internet Information Office will conduct } \\
\text { regular supervision and inspection, the violators will be punished } \\
\text { according to the severity of the behavior. }\end{array}$ \\
\hline
\end{tabular}


All in all, with the development of Internet, the connection between government work and the Internet is becoming more and more closely. The introduction of the above laws and regulations has important guiding significance for the government in opening government information, guiding network public opinion, and ensuring Internet information security, which is conducive to further promoting and standardizing the development of the Internet and improving the level of government's network governance. But at present, China has not yet issued specific laws and regulations aiming at the guidance network public opinion, and lacks corresponding legal basis in actual guiding work, which is insufficient in guiding the specific guidance work. Moreover, the Central Information Office and the Local Network Information Office have not yet issued the specific implementation policies for the network public opinion guidance and the guiding work of network public opinion lacks specific direction.

\section{The Government's Current Way of Guiding Internet Public Opinion}

In recent years, the work of local government departments has gone from "offline" to "online". They have launched official micro-blog, We-Chat and client, to seize the new position of Internet public opinion. As of December 2016, the number of online government service users in China reached 239 million, being accountable for $32.7 \%$ of the total Internet users. The country is comprised of 53546 gov.cn domain names, 164522 government micro-blog and 34083 government headlines. [10] With the development of online government affairs, the usage rate of the online service for Internet users in China in 2016 has exceeded the usage rate of government administration hall and government hotline. As showed in Figure 1:

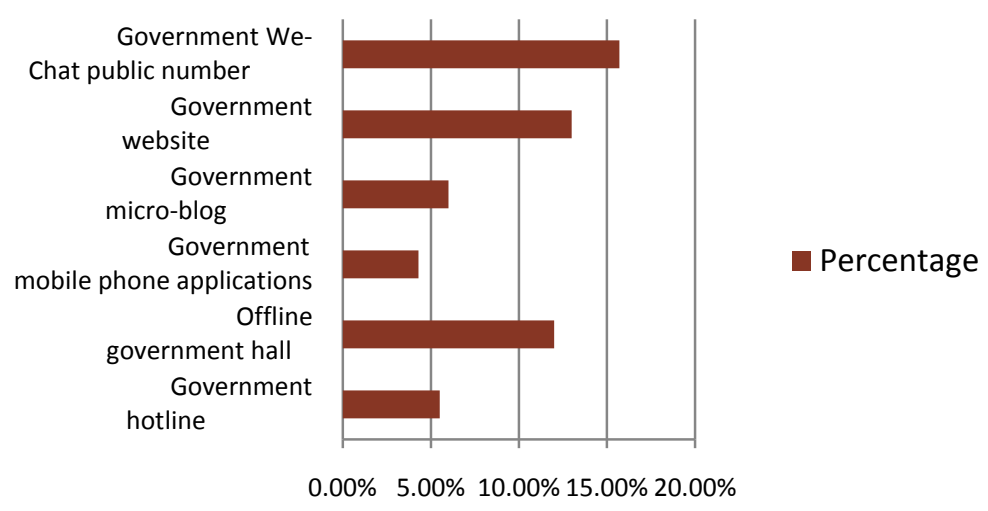

Fig 1. Usage rate of net citizen in public services in 2016

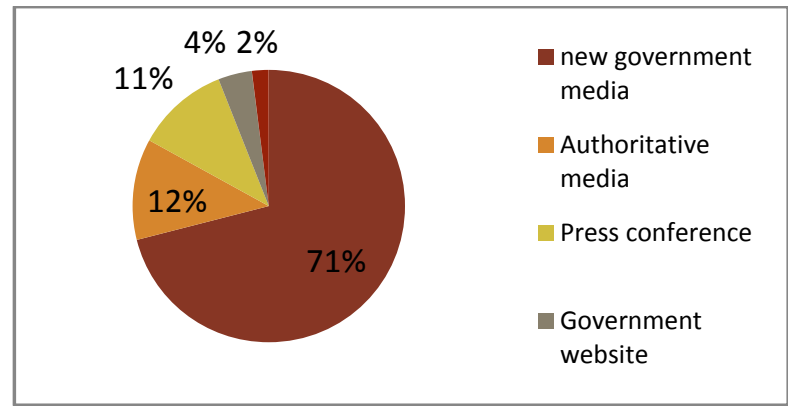

Fig 2. Transmission platform of social hot spots and public opinion

New government media have widened the scope of online government services and brought new opportunities for the release of information and became the main position of information interaction and guidance of network public opinion. In addition, in some major network broadcast opinion events, Press conferences are also an important way to guide public opinion. Nowadays, the government has gradually set up a variety of public opinion response channels, such as a news 
conference, new government media and mainstream media, aimed at strengthening information disclosure, expanding mainstream voice and effectively guiding network public opinion. As showed in Figure 2:

In addition, many scientific research institutes in China are monitoring and judging the network public opinion and social public opinion, providing data support for the government to effectively guide the network public opinion. Since its establishment in 2008, People's network public opinion monitoring Office has conducted 24-hour monitoring on various types of network public opinion media and carried out professional statistics and analysis to form a monitoring and analysis research report and continued to publish public opinion monitoring information on its We-Chat Official, it becomes an authoritative source of data and important public opinion information of the party and government organs. Some universities rely on the advantages of their own disciplines to establish public opinion laboratories, more outstanding with the Tsinghua University School of Journalism and communication and Youxun era (Beijing) Network Technology Co., Ltd. jointly established Tsinghua University News public opinion laboratory, it provides public opinion monitoring data and effective guidance for government departments, in order to promote the ability to guide the government. Mobile, Unicom and telecom, the three major communications companies have become an effective way for the government to monitor public opinion based on their data advantages and status of state-owned enterprises.

In summary, the government's current methods of guiding online public opinion mainly include applying new media of government affairs, promoting the advantages of traditional authoritative media, holding press conferences, improving the information disclosure of government websites, combined with third-party scientific research institutes and relying on communications companies for data monitoring and so on, a variety of ways to coordinate and make the government play a role in a better guide the network of public opinion. However, due to the appeal of multiple interests, the speed of network public opinion has been accelerating and the range is expanding, the number of subjects involved is increasing, and the government's guidance to network public opinion still has many shortcomings, which need further improvement.

\section{The Predicament and Challenge of the Guidance of Network Public Opinion}

At present, Chinese government according to the network of public opinion work has issued a series of laws and regulations and policies, and has adopted some effective means and methods. However, due to the ever-changing network of public opinions, new situations and new problems emerge one after another; challenging the government's ability to guide public opinions on the Internet, the government urgently needs innovative ways of working so as to get out of the predicament of the network of public opinion.

\section{The Government's Judgment on the Network Public Opinion is not in Place}

The government's judgment on network public opinion means refers to the government's judgment of the value and trend of the qualitative and quantitative network public perspective. It tracks the routine and continuity of network shared opinion, and judges the level of public opinion for a sudden event or a specific task. First of all, we should distinguish between public opinion and rumors, true public opinion and false public opinion, so as to achieve an accurate grasp. Secondly, the relevant information of true public opinion is summarized and classified, and rumor or deceiving public opinion is refuted. Finally, the systematic analysis should be carried out according to the summary information, whether or not the judgment on internet public opinion is comprehensive, accurate and timely is the result of guidance from the whole network public opinion.

In recent years, Chinese government has paid more attention to the work of network public opinion guidance, some outstanding government affairs micro-blog and We-Chat Official account can quickly analyze and declare the network public opinion and make the response. It plays a major role in the guidance of network shared perspective. However, some government or functional departments have a couple of problems in judging network public opinion. Specifically is: 
First, cognition of network shared opinion is inaccurate. Prone to three cases, one is paid no attention to the network of public opinion, not take action not to respond; secondly, we pay too much attention to Internet public opinion and blindly follow the network broadcast perspective. Three, we regard network opinion as the most popular Internet opinion as network public opinion. The three cognitive mistakes will not only misjudge the network public opinion, but also encourage the network of public opinion into the fermentation period in advance, which may cause greater obstacles to the government's guidance work.

Second, the information of collecting and arranging of network public opinion is not part of place. The collection and arrangement of information are the basis and basis for judging the trend of network public opinion. However, in the face of a lot of information on the Internet, the government often cannot find the necessary information quickly or miss unobservable useful information. In addition, the lack of routine monitoring has also greatly affected the collection of data.

Third, the government's judgment on the trend of network public opinion is not in place. Judging the tendency is the most important part of the effective guidance, and a little inadvertent is likely to be counterproductive. While some governments are lack of foresight and general connection in guiding network public perspective, they cannot predict and plan accurately. In guiding network public opinion, they always lag behind the change of network public opinion, which leads to the passive work of guidance.

\section{Lack of Effective Application of New Government Media}

Table 2.The specific performance of the government's insufficient application ability to the new government media

\begin{tabular}{|c|c|c|}
\hline category & content & Specific performance or specific case \\
\hline $\begin{array}{l}\text { Government } \\
\text { micro-blog }\end{array}$ & $\begin{array}{l}\text { Government micro-blog } \\
\text { has a bureaucratic voice, } \\
\text { Low service consciousness }\end{array}$ & $\begin{array}{l}2015 \text { Harbin fire, Harbin official micro-blog@ safe Harbin released } \\
\text { a } 585 \text { word notification,” the leadership high attention,” accounting } \\
\text { for half, causing net citizens discontent }\end{array}$ \\
\hline $\begin{array}{l}\text { Government } \\
\text { We-Chat } \\
\text { public } \\
\text { number }\end{array}$ & $\begin{array}{l}\text { The platform is not perfect, } \\
\text { Service mechanism is not } \\
\text { perfect }\end{array}$ & $\begin{array}{l}\text { After the opening of some government We-Chat public numbers, } \\
\text { they pursue "partial, big and complete” in Daily Publishing contents. } \\
\text { People's livelihood information is not released enough, and push is } \\
\text { not in time. It is difficult to play the role of government We-Chat } \\
\text { public number in accurately interpreting public opinion and guiding } \\
\text { public opinion. }\end{array}$ \\
\hline $\begin{array}{l}\text { Government } \\
\text { affairs } \\
\text { client(APP) }\end{array}$ & $\begin{array}{l}\text { Low total downloads, } \\
\text { low permeability, } \\
\text { Low update frequency }\end{array}$ & $\begin{array}{l}\text { SUN YAT-SEN University government APP (client) research group } \\
\text { released survey data of } 70 \text { domestic popular city government clients } \\
\text { in } 2015 \text {. The download rate of government affairs clients is less than } \\
1 / 10 \text { of that of commercial clients, and the penetration rate of } \\
\text { first-tier cities is less than } 40 \% \text { and } 60 \% \text { government clients in } 3 \\
\text { months from not updated }\end{array}$ \\
\hline $\begin{array}{l}\text { Government } \\
\text { portal }\end{array}$ & $\begin{array}{l}\text { The information content of } \\
\text { the website is updated } \\
\text { slowly or not, and many } \\
\text { columns appear unable to } \\
\text { access the phenomenon }\end{array}$ & $\begin{array}{l}\text { The office of the State Council reported on the second national } \\
\text { government website spot checks in 2016, and the website of } \\
\text { "Mengla County Protection Institute" in Yunnan province has not } \\
\text { been updated over } 6 \text { years; Fu'an City, Fujian Province, "Xiao Yang } \\
\text { Town People's Government" there are a lot of blank column } \\
\text { network; A large number of columns can't be accessed by } \\
\text { "Shouyang County Environmental Protection Agency" network in } \\
\text { Shang Xi province }\end{array}$ \\
\hline $\begin{array}{l}\text { Other } \\
\text { emerging } \\
\text { government } \\
\text { new media }\end{array}$ & $\begin{array}{l}\text { Lack of knowledge and } \\
\text { less application }\end{array}$ & $\begin{array}{l}\text { Some of the emerging self-media forms such as webcasting, } \\
\text { know-it-yourself, and micro-video are already beginning to be used, } \\
\text { but they have not drawn enough attention from most government } \\
\text { departments }\end{array}$ \\
\hline
\end{tabular}

New government media initially refer to the general name of government micro-blog, government affairs We-Chat, government's client and government website. With the development of Internet, its connotation expands ceaselessly, Jin Ting defines it as "a new media platform for government agencies, public service agencies and government officials with real public office credentials to carry out their work related to government affairs activities, providing public affairs 
services, communicating with the people and asking political parties over the Internet"[11] Of the more than 600 government public opinion cases that the government responded to in 2016, about $41 \%$ of the information distribution channels were used by government new media.[12]Therefore, the use of government different media to guide public opinion is an important way and means for the government. The government uses the government additional media to guide the network public opinion to be remarkable, but its shortcomings are also increasingly exposed. As showed in Table 2:

Through the review of the government's application of various types of government affairs new media, we found that the government micro-blog did not respond properly, the follow-up actions of the government affairs We-Chat ineffective, the government client's push information was not timely, the government portal's information was not open and transparent, or interception of the second-shot video of misconduct by government officials will make the ordinary events complicated, which makes the network of public opinion against the government, the government in a difficult situation equally difficult to go on or retreat.

Secondary public opinion refers to a series of recent public opinion induced by the native public opinion. In a broad sense, there is a trend of positive and negative public opinion. In the narrow sense, it refers to the phenomenon that original public opinion is a negative network event or may lead to undesirable secondary public opinion. This article adopts the narrow sense of secondary public opinion, which refers to a wider range of public opinion caused by improper response to the original public opinion or the report of central events, which are a secondary disaster crisis of public opinion. When such behavioral agent is government, it will not only make the handling of related events more complex, but also make the government suffer more doubts and damage the credibility of the government.

\section{The Government’s Improper Disposal Triggered Secondary Public Opinion}

From the emergence of network public opinion to fermentation and then to the climax, improper disposal by the government can easily speed up the ferment of internet public opinion and even detonate public opinion ,so that it enters the climax ahead of time, resulting in frequent secondary public opinion, thus increasing the pressure and difficulty of government guidance. According to Xinhua-net recently release the “ 2016 Data Analysis of Social Hot Public Opinions,” it summarizes the triggered secondary public opinion events in the social field in 2016 and combed the behavior of government's improper disposal. Specific as showed in Table 3:

Table 3. Events triggered secondary public opinion in social field in 2016

\begin{tabular}{|c|c|c|c|c|}
\hline Serial number & Time & & Event & Disputed situation \\
\hline One & Jan & Gansu & $\begin{array}{l}\text { Many journalists in Gansu were } \\
\text { involved in blackmail arrest }\end{array}$ & There is "revenge" suspects \\
\hline Two & Feb & $\begin{array}{l}\text { Hei } \\
\text { Longjiang }\end{array}$ & Harbin”high price fish” event & $\begin{array}{l}\text { Reversal of public opinion } \\
\text { show no consistency }\end{array}$ \\
\hline Tree & Mar & Shandong & Shandong issue of the vaccine event & $\begin{array}{l}\text { Response is no professional and } \\
\text { no meticulous }\end{array}$ \\
\hline Four & Apr & Jiangsu & $\begin{array}{l}\text { ChangzhouForeign Language } \\
\text { School pollution event }\end{array}$ & Response to lack of pertinence \\
\hline Five & May & Hebei & $\begin{array}{l}\text { Zhangjiakou"grassland heaven" } \\
\text { incident }\end{array}$ & $\begin{array}{l}\text { Different interpretation of } \\
\text { standard application }\end{array}$ \\
\hline Six & May & Beijing & Lei Yang event & Law enforcement is not standard \\
\hline Seven & Jun & Hubei & $\begin{array}{l}\text { Xiantao garbage incineration project } \\
\text { incident }\end{array}$ & $\begin{array}{l}\text { A variable response and a lack of } \\
\text { foresight }\end{array}$ \\
\hline Eight & Jul & Hubei & $\begin{array}{l}\text { Wuhan } 13 \text { billion flood control } \\
\text { funding cited query }\end{array}$ & $\begin{array}{l}\text { Propaganda is not consistent with } \\
\text { reality, net citizens make a sway }\end{array}$ \\
\hline Nine & Jul & Hebei & Xingtai Daxian Village flood events & $\begin{array}{l}\text { Different departments (related } \\
\text { personnel) talk about fighting }\end{array}$ \\
\hline Ten & Nov & Gansu & $\begin{array}{l}\text { Lanzhou University of Finance and } \\
\text { Economics bread "mildew" event }\end{array}$ & Overreact \\
\hline
\end{tabular}

Data source: Xinhuanet. Public opinion network”2016 social hot events network public opinion report” 
The improper disposal of the government mainly in three aspects: First, the government's inaction, chaos and mutual restraint, such as government non-standard law enforcement, different departments say contradictions ; second, the government responded to insincere and lack of ways, for example, when talking about mandarin and lack of professionalism and so on; Thirds, the government's disclosure of the truth of the incident was not timely or there was a cover-up of the truth, for example, inconsistency before and after the response. The misconduct of the government in the process of guiding will not only make the relevant departments become new "groove" for the public, but will also make the results of the incident unfair and even cause the government to become a target of public criticism and be deeply trapped in Tacitus trap. Once the credibility of the government is damaged, it not only threatens the authority of government, but also is not conducive the stability and harmony of society and the long-term stability of the country.

\section{The Lack of Effective Integration of Online and Offline Processing}

The capacity of government to guide network public opinion is a collection of online grooming and offline processing ability. These can be overlooked. If we focus only on online processing, it will ignore the root causes of network shared perspective, which leads to unsatisfied public interest demands. If only concentrate on offline processing, it is difficult to grasp the changes in real-time network broadcast perspective, which causes the government to fall into the whirlpool of responding to the ineffective public opinion on the network. The current government guidance on the network public opinion lacks the effective combination of online guide and offline processing.

First, there is not enough online grooming capability. Online grooming refers to the use of network technology and the dissemination characteristics of Internet information to sort out and guide network public opinion. In order to contribute to the public identifies the truth and guide rational voice. It is mainly reflected in the lack of capacity for the application of new media tools and the ability to actively set topics. For further media tools, for the modern media tools, it is needed for the government to know clearly its respective advantages and functions in guiding network public perspective, so that the government's guidance can be played with a multiplier effect. The initiative to set the agenda is the use of agenda setting theory, the initiative setting up a topic is to use the agenda setting theory, the information accepted by the public is put in place to influence the public opinion and achieve the guiding effect. But in reality, the government has been criticized for its application innovative media tools. Some government departments freely publish news in government affairs micro-blog and We-chat, disregarding the community perspective consequences. Some government departments to publish some unrelated government articles in the use of government different media, making it difficult for the government to give full play to the natural advantages of innovative media tools to guide network public opinion. In addition, the initiative to set up the agenda is an important tool for guiding the network shared perspective, which can make the network public opinion in the direction of government's hope. However, some government departments do not pay no mind to the setting of an agenda or lack the ability to voluntarily set agenda. This has led to the loss of the initiative agenda setting and the government often falls into the dilemma in guiding work.

Secondly, the ability of offline processing is not sufficient. Offline processing capability refers to the ability to identify and deal with the principal events of network public opinion and other related events and to obtain the corresponding result. It includes incident's official notification, follow-up, follow-up treatment and transparent information and so on. In recent years, most of the Internet how events come from real life. Network public perspective is constituted by internet fermentation. Effective offline processing is the key to quelling the network shared opinion. However, there are two major problems in the government's capability to deal with network public opinion :

First, it is not active and ineffective in the process of event handling. Mainly for non-disclosure of the truth of the incident, follow-up of the incident did not share the results and the consequences are not released, or the existence of favoritism and favoritism, to cover the fault square and so on. The most typical case was exposed in Binhai New Area in Tianjin in 2015. After the bombing, the officials in Tianjin held an excuse "not clear" or "misunderstanding" on various issues of public 
concern before the six press conferences. Thus, it shows that when the offline processing capacity is deficient, it will accelerate the fermentation and expansion of the network public opinion, and increase the difficulties of guiding work.

Thirdly, the event's consequence by the influence of the media network is too large. With the emphasis on network public opinion, some government departments and government staff immediately deal with the responsible persons without any investigation and research on their own online opinions and public opinions. Even in the process of handling events, some government departments did not follow the laws, regulations and legal procedures and expanded the influence of network shared opinion on events, ignoring the principle of objectivity and fairness. These two situations fail to achieve the government's requirement of effectively guiding network public opinion and will indulge the development of the network of public opinion, so that the public may overly rely on the power of public opinion without regard to laws and regulations and ultimately may lead network public opinion into the violence of public opinion affect the social order, or be used by people who are interested in attacking the government, undermining social harmony and stability.

\section{The System of Network Public Opinion Classification Response is not Perfect}

Government guidance on the network of public opinion often do not know how to deal with or how to guide the dilemma, due to unsound professional mechanism of government guidance of network public opinion is not perfect, the lack of grading response mechanism for network public opinion and the mechanism for guiding professional personnel, the government has no basis to deal with and guide network public opinion and many government staffs with a great deal of affairs are unable to achieve effective guidance when dealing with and guiding network public opinion. With the continuous development of network public opinion, the unsound professional mechanism has gradually become the institutional barrier that it promotes government's guidance ability.

At present, from the national level, the classification mechanism of network public opinion in China is the warming level mechanism of network public opinion. It is divided into four levels: light alert, moderate alert, heavy alert and extra heavy alert, as showed in table 4:

Table 4. China’s network public opinion warning level

\begin{tabular}{|l|l|l|l|l|}
\hline name & degree & color & level & representation \\
\hline Light alert & $\begin{array}{l}\text { Non } \\
\text { normal } \\
\text { level }\end{array}$ & blue & IV & $\begin{array}{l}\text { Domestic net citizens have low attention to the public opinion, slow } \\
\text { propagation speed and small influence on public opinion, which is not } \\
\text { likely to be translated into behavioral public opinion }\end{array}$ \\
\hline $\begin{array}{l}\text { moderate } \\
\text { alert }\end{array}$ & $\begin{array}{l}\text { Warming } \\
\text { level }\end{array}$ & yellow & III & $\begin{array}{l}\text { Domestic net citizens have high attention to the public opinion, medium } \\
\text { propagation speed the influence of public opinion is within a certain } \\
\text { range, which is not likely to be translated into behavioral public opinion }\end{array}$ \\
\hline $\begin{array}{l}\text { Danger } \\
\text { level }\end{array}$ & orange & II & $\begin{array}{l}\text { Domestic net citizens have high attention to the public opinion, and the } \\
\text { overseas media begin to pay attention to it, fast propagation speed, the } \\
\text { influence spreads to a great extent, which is likely to be translated into } \\
\text { behavioral public opinion }\end{array}$ \\
\hline heavy alert & $\begin{array}{l}\text { Extreme } \\
\text { danger } \\
\text { level }\end{array}$ & red & I & $\begin{array}{l}\text { Domestic net citizens are extremely concerned about the public opinion, } \\
\text { the overseas media pay high attention, very fast propagation speed, the } \\
\text { influence has been extended to the entire society, public opinion will } \\
\text { become behavioral public opinion }\end{array}$ \\
\hline
\end{tabular}

Four warning levels are divided by different degrees of network public opinion play a guiding role in guiding the network public opinion, but it is far from the standard of the network opinion classification and response mechanism required by the government. This lack of network public opinion classification and response mechanism are: first, the classification mechanism isn't perfect and the government lacks the objective division standard when dealing with online public opinion; second, the hierarchical response mechanism is not perfect, it is difficult to carry out effective measures in a targeted manner, when the government guides the network public opinion. It will 
result in the government failing to grasp the key points in guiding network public opinion and result in the waste of government resources.

\section{Construction of Matrix -Oriented Network Public Opinion Guidance Layout}

Matrix-oriented guidance refers to the guide mode which the network public opinion is coordinated by the upper and lower levels of the system, or regional department and state sector, mainly manifested as the linkage between new government media, the various departments under the line, the interactive guidance of various systems and other government departments, the synergistic cooperation between online government new media and offline governance, and so on, resulting in a strong effect of public opinion in guiding the polymerization. This model can optimize the guiding process, improve guiding efficiency, save guiding cost and solve the risk of public opinion. In recent years, network public opinion has been developing towards diversification, industrialization and nationalization. Therefore, we should construct a matrix-oriented guide layout and release it in a coordinated manner, which will play a role of linkage guidance in network public opinion.

\section{Enhancing the Linkage Effect between New Government Media}

The new government media including micro-blog, We-Chat and client and other government new media on the same or related news linkage release, can form information in cyberspace encirclement, allowing rapid spread of information at the same time, and influence the network public opinion of public opinion events through constant repetition of providing similar information, so as to better guide the network public opinion.

First of all, fully understand the guiding advantages of various types of new government media, this is the prerequisite for the effective application of the new government media. Government micro-blog refers to opening the micro-blog account in the micro-blog website by all levels of government agencies and public officials with their real identity and information. ${ }^{[13]}$ It is open and interactive and can be used for information disclosure, timely response and interaction with citizens. We can use micro-blog's topic function to set up topics actively and affect the trend of public opinion. The audience of government affair is mainly We-Chat users. They can carry out a deep interpretation of related policies and knowledge by pushing articles and setting up functional modules, and their followers will spread the article to friend zone, which will influence on network opinion public events. Use the government client to do a general and authoritative commentary on public event, and strengthen guidance by pushing long articles and collecting citizens' comments. Only by fully understanding the advantages of various types of government new media can we guide network public opinion effectively.

Secondly, according to the actual situation, its function is integrated, so that the linkage effect can be maximized. For example, in emergencies and major events, to ensure the rapid spread of information, we must first select micro-blog to release news continuously; after ceasing the rumor, citizens become rational, government We-Chat channel can be used to push Detailed Articles, let information spread out more accurately.

Finally, the government should strengthen the communication and interaction between the new government media, and pay attention to communication in the news release linkage; committed to the formation of government cooperation in new media to guide the network public opinion, rather than pulling each other or reducing the effective guidance. Therefore, all kinds of new government media operators need to strengthen communication to ensure the consistency in guiding direction, which is also an important guarantee for the linkage effect.

\section{Strengthening the Coordinated Publishment of Government and Network Opinion Leaders}

Opinion leaders refer to those who are active in the network of interpersonal communication and often provide others information, views or suggestions and exert personal influence on Internet users.[14] Network opinion leader refers to the people or organizations that are active in the network group communication venues, and express the personification and ability characteristics through active speech, affecting the dissemination of information and the expression of common 
topics. [15] In recent years, with the development of Internet, some government departments and authoritative mainstream media pay more attention to the operation of government new media, and at the same time, they have become the authoritative opinion leaders that influence the trend of online media due to the authority of their entities.

In addition, there are many individual-led opinion leaders on the Internet, such as some well-known scholars, celebrities and entertainment stars, based on the huge amount of fans and communication power, their concerns and comments on the network public opinion events can affect the spread Speed and direction of network public opinion. Therefore, the government should strengthen the collaborative release with the network opinion leaders and use the influential network opinion leaders to help the government guide network public opinion in a better way.

On the one hand, the government should do a good job of coordinating the issuance of opinions with network government affairs opinion leaders. Strengthen communication with the network government affairs opinion leaders, achieve collaborative release and speed up the spread of information in a short period of time. For example, in the guidance of network public opinion, the first-hand information released by small or medium size government-owned micro-enterprises can be coordinated and released with CCTV news, @Public security ministry and other network government affairs opinion leaders, spread the information correctly and eliminate the rumor.

Micro-blog opinion leaders' reports often become the news sources of traditional media on authoritative information of public events, and make up for the lack of timeliness of traditional media. We can also give full play to the authoritative role of network government affairs opinion leaders, to relieve the pressure of network public opinion by pushing the articles of the authoritative commentators and detailed graphics and etc., so that these will affect the trend of the network of public opinion. At the same time, it is necessary to do a good job of collaborating with the network individual opinion leaders, the opinions and comments of the individual opinion leaders on the network will greatly influence the opinion of their followers. In particular, the attitude of entertainment stars with millions of fans on the public events will greatly affect the tendency of public opinion. The government should attach importance to the influence of individual opinion leaders on the network, and influence the direction of network public opinion through interaction, open support and collaborative publishing, so as to guide the network public opinion more effectively.

\section{Promoting Coordination and Cooperation between Online Guidance and Offline Governance}

To build a matrix layout, we should do well in online guidance. Besides, we should do well in offline governance. Internet public opinion is the response of real problems on the Internet. The effectiveness of guidance ultimately depends on the effectiveness of offline governance. Therefore, only by strengthening the coordination and cooperation between government online guidance and offline governance, can we have the effect of tackling both the symptoms and the root cause in the guidance of network public opinion.

First of all, the government should intensify the communication and connection between online guidance and offline governance, this connection is reflected in the effectiveness of online guidance to set aside more time and space for offline governance, the result of offline governance is continuously updated on the guidance to provide information, in such good interactions to effectively guide the network public opinion. Secondly, we should give full play to the role of "ballast" in the public opinion of the traditional offline media. Give full play to the advantages of traditional media in terms of influence and credibility, and achieve the coordination and cooperation between online guidance and offline governance through the online guidance of publishing the in-depth reports and news comments of traditional media on the network public opinion events, so as to affect the trend of network public opinion. Finally, we should adopt proper handing approaches to ensure the coordination and cooperation between the online guidance and the offline governance. In other words, government departments should respond promptly to queries and criticisms on the Internet, promptly investigate the central events of the network public opinion, and 
handle the events reasonably and legally, so as to not only know the public's appeals, but also deal with them objectively and fairly.

In short, network public opinion has become an important manifestation of social public opinion. The government strengthens guidance of the network public opinion, which is the concrete manifestation of promoting the network governance and practicing the strategy of the network power. Constructing a matrix-oriented network public opinion guidance layout will help the government to further strengthen correct guidance of the network public opinion and improve network government level and ability.

\section{References}

[1] Chinese Government Network. Regulation of the People's Republic of China on the disclosure of Government Information [EB/OL]. http:/www.gov.cn/xxgk/pub/govpublic/tiaoli.html

[2] Chinese Government Network. The decision of the Standing Committee of the National People's Congress on strengthening the protection of network information [EB/OL]. http://www.chinalaw.gov.cn/article/fgkd/xfg/fl/201212/20121200379613.shtml

[3] Chinese Government Network. General Office of the State Council further strengthens government information to respond to social concerns and enhance the credibility of the government [EB/OL]. http://www.gov.cn/zwgk/2013-10/15/content_2506664.htm

[4] The Supreme People's Procuratorate of the People's Republic website of china. Interpretation of several issues about the law applicable in criminal cases such as defamation of the use of information network by the Supreme People's Court and the Supreme People's Procuratorate[EB/OL]. http://www.court.gov.cn/ shenpan-xiangqing-5820.html

[5] Chinese Government network. Notifications of further response to government public opinion in the public affairs[EB/OL]. http://www.gov.cn/zhengce/content/2016-08/12/content_5099138.htm

[6] Chinese Government network. Opinions on promoting the public work of government a-fairs in an all-round way(implementation rules)[EB/OL].

http://www.gov.cn/zhengce/content/2016-11/15/content_5132852.htm

[7] People's Republic of China National Internet Information Office portal. Internet broadcast service management regulations [EB/OL]. http://www.gov.cn/2016-11/04/c_1119847629.htm

[8] Chinese Government network. National network security law[EB/OL]. http:// /www.chinalaw.gov.cn/article/fgkd/xfg/fl/201611/20161100482148.shtml

[9] People's Republic of China National Internet Information Office portal. Internet news information service management regulations[EB/OL].

http://www.cac.gov.cn/2017-05/02/c_1120902760.htm

[10] China center of Internet Information. The thirty-ninth "Statistical Report on Internet Development in China"

[11] Jin Ting. Analysis on the development status and exist problems and Countermeasures of new government media, [J]. E-government, 2015(8):22

[12] Chen Xiaoran. Government micro-blog improper sound, why is always being you [EB/ OL]. People's Network public opinion testing center

[13] Jiang Xiumin, Chen Huayan. The practice model and development path of Chinese government micro-blog[J].Journal of Northeastern University: Social Science Edition.2014.16(1):64.

[14] Guo Xueguang. Communication Course[M].Beijing: China Renmin University press,1999:23. 
[15] Bao $\mathrm{Xu}$. The main network of opinion leaders and interactive analysis[J]. News dissemination,2012(7):81-82

[16]Sheng Qizhi, Gao Yusen. Chinese micro-blog opinion leader: characteristics, types and trends of development [J]. Journal of Northeastern University: Social Science Edition, 2013(4):385. 